\title{
Photosynthetic responses of young cashew plants to varying environmental conditions
}

\author{
Rogéria Pereira de Souza ${ }^{(1)}$, Rafael Vasconcelos Ribeiro(1), Eduardo Caruso Machado(1), \\ Ricardo Ferraz de Oliveira ${ }^{(2)}$ and Joaquim Albenísio Gomes da Silveira ${ }^{(3)}$
}

\begin{abstract}
(1)Instituto Agronômico, Centro de Pesquisa e Desenvolvimento em Ecofisiologia e Biofísica, Caixa Postal 28, CEP 13001-970 Campinas, SP, Brazil. E-mail: souzarp@yahoo.com, rafael@iac.sp.gov.br, caruso@iac.sp.gov.br (2)Universidade de São Paulo, Escola Superior de Agricultura Luiz de Queiroz, Dep. de Ciências Biológicas, Caixa Postal 9, CEP 13400-970 Piracicaba, SP, Brazil. E-mail: rfolivei@esalq.usp.br (3)Universidade Federal do Ceará, Dep. de Bioquímica e Biologia Molecular, Caixa Postal 6020, CEP 60451-970 Fortaleza, CE, Brazil. E-mail: silveira@ufc.br
\end{abstract}

\begin{abstract}
The aim of this study was to characterize gas exchange responses of young cashew plants to varying photosynthetic photon flux density (PPFD), temperature, vapor-pressure deficit (VPD), and intercellular $\mathrm{CO}_{2}$ concentration $\left(\mathrm{C}_{\mathrm{i}}\right)$, under controlled conditions. Daily courses of gas exchange and chlorophyll a fluorescence parameters were measured under natural conditions. Maximum $\mathrm{CO}_{2}$ assimilation rates, under optimal controlled conditions, were about $13 \mathrm{mmol} \mathrm{m}^{-2} \mathrm{~s}^{-1}$, with light saturation around 1,000 $\mathrm{mmol} \mathrm{m}^{-2} \mathrm{~s}^{-1}$. Leaf temperatures between $25^{\circ} \mathrm{C}$ and $35^{\circ} \mathrm{C}$ were optimal for photosynthesis. Stomata showed sensitivity to $\mathrm{CO}_{2}$, and a closing response with increasing $\mathrm{C}_{\mathrm{i}}$. Increasing VPD had a small effect on $\mathrm{CO}_{2}$ assimilation rates, with a small decrease above $2.5 \mathrm{kPa}$. Stomata, however, were strongly affected by VPD, exhibiting gradual closure above $1.5 \mathrm{kPa}$. The reduced stomatal conductances at high VPD were efficient in restricting water losses by transpiration, demonstrating the species adaptability to dry environments. Under natural irradiance, $\mathrm{CO}_{2}$ assimilation rates were saturated in early morning, following thereafter the PPFD changes. Transient $\mathrm{F}_{\mathrm{v}} / \mathrm{F}_{\mathrm{m}}$ decreases were registered around $11 \mathrm{~h}$, indicating the occurrence of photoinhibition. Decreases of excitation capture efficiency, decreases of effective quantum yield of photosystem II, and increases in non-photochemical quenching were consistent with the occurrence of photoprotection under excessive irradiance levels.
\end{abstract}

Index terms: Anacardium occidentale, gas exchange, chlorophyll fluorescence, temperature, vapor-pressure deficit.

\section{Respostas da fotossíntese à variação das condições ambientais em plantas jovens de cajueiro}

Resumo - O objetivo deste trabalho foi caracterizar as respostas das trocas gasosas de plantas jovens de cajueiro à densidade de fluxo de fótons fotossintético (DFFF), temperatura, déficit de pressão de vapor (DPV) e concentração interna de $\mathrm{CO}_{2}\left(\mathrm{C}_{\mathrm{i}}\right)$, sob condições controladas. Cursos diários das trocas gasosas e de variáveis de fluorescência da clorofila a foram obtidos sob condições naturais. A taxa de assimilação de $\mathrm{CO}_{2}$ máxima foi de cerca de $13 \mathrm{mmol} \mathrm{m}^{-2} \mathrm{~s}^{-1}$, com saturação pela luz em torno de $1.000 \mathrm{mmol} \mathrm{m}^{-2} \mathrm{~s}^{-1}$. As temperaturas das folhas entre $25^{\circ} \mathrm{C}$ e $35^{\circ} \mathrm{C}$ corresponderam à faixa ótima para a fotossíntese. Os estômatos mostraram-se sensíveis ao $\mathrm{CO}_{2}$ e se fecharam com aumentos de $\mathrm{C}_{\mathrm{i}}$. Aumentos do DPV exerceram pequeno efeito sobre a taxa de assimilação de $\mathrm{CO}_{2}$, com uma pequena diminuição acima de 2,5 kPa. Os estômatos, no entanto, foram fortemente afetados pelo DPV, com fechamento gradativo acima de 1,5 kPa. As condutâncias estomáticas, reduzidas em altos DPVs, foram eficientes em restringir as perdas de água pela transpiração e demonstraram adaptação da espécie a ambientes secos. Sob irradiância natural, a taxa de assimilação de $\mathrm{CO}_{2}$ apresentou saturação no início da manhã, variando posteriormente com as variações da DFFF. Decréscimos transientes da razão $F_{v} / F_{m}$ foram registrados em torno de 11h, o que indica a ocorrência de fotoinibição. Decréscimos da eficiência de captura da energia de excitação, decréscimos da eficiência efetiva do fotossistema II e aumentos da extinção não-fotoquímica foram consistentes com a ocorrência de fotoproteção sob irradiância excessiva.

Termos para indexação: Anacardium occidentale, trocas gasosas, fluorescência da clorofila, temperatura, déficit da pressão de vapor. 


\section{Introduction}

Cashew (Anacardium occidentale L.) is a perennial tropical species native to the Brazilian Northern Coast, where they have an important economic role (Lima, 1988). The species occupies an outstanding position among tree crops, in view of the commercial value of its nuts. Commercially important orchards are also found in the Eastern and Western Coasts of Africa, Northern Australia, Fiji Islands, Hawaii and Southern Florida (Lima, 1988). In Brazil, low crop productivity has been attempted to be solved with the introduction of new commercial dwarf clones with high productivity associated to precocious production (Barros et al., 2000).

Empirical observations have shown that cashew plants may present adaptation to a relatively large ecological range (Lima, 1988), growing well in both low and medium land tropical regions (Mendes-Ferrão, 1995). The lack of information about the species is due to limited research considering physiological aspects (Marler et al., 1994). Some studies were developed in Australia, such as: Schaper \& Chacko (1993), on the influence of leaf age and branch girdling on gas exchange; Schaper et al. (1996), on the effects of irrigation on gas exchange and leaf water status; and Blaikie \& Chacko (1998) and Blaikie et al. (2001), on sap flow and leaf photosynthesis as affected, respectively, by soil drying and irrigation strategies. Balasimha (1991), and Palanisamy \& Yadukumar (1993) have also studied the photosynthetic characteristics of adult cashew trees in India. In Brazil, research on salinity affecting nitrogen metabolism, and solute accumulation in young cashew plants have been also carried out (Viégas \& Silveira, 1999; Viégas et al., 1999).

The aim of this study was to characterize the photosynthetic response of young cashew plants to variations of environmental conditions.

\section{Material and Methods}

The study was carried out on cashew plants (Anacardium occidentale L.), dwarf clone CP06, grown from seeds originated from plants grafted on theirselves as rootstocks and provided by Embrapa Agroindústria Tropical. The seedlings were cultivated on $2.8 \mathrm{~L}$ pots containing silica:vermiculite $(1: 1)$ in a greenhouse situated at the Experimental Station of Instituto Agronômico, Campinas, SP, Brazil (22 ${ }^{\circ} 54^{\prime} \mathrm{S}$ and 4705'W, 674 m altitude).
Seeds were directly sown in pots, after being soaked in distilled water for 24 hours. One month after sowing, plants began to receive Hoagland and Arnon's nutritive solution (Hoagland \& Arnon, 1938) twice a week, being irrigated with distilled water in the remaining days. In the first two weeks, nutritive solution was supplied in one-tenth (first week), and half (second week), of its ionic strength. Measurements were taken from three to five 45-55 day-old plants.

For evaluation of gas exchange responses, plants were transferred to a growth chamber (Conviron E15, Canada), under controlled temperature $\left(30^{\circ} \mathrm{C}\right)$, photosynthetic photon flux density (PPFD) of $300 \mu \mathrm{mol} \mathrm{m}{ }^{-2} \mathrm{~s}^{-1}$; and air vapor-pressure deficit (VPD) of $1.5 \mathrm{kPa}$.

Measurements were taken after one hour acclimation period in the growth chamber, in completely expanded leaves, with a Portable Photosynthesis System (Li-6400, Li-Cor, USA), equipped with a red light source and a leaf chamber.

For obtaining response curves to variations of PPFD, temperature, VPD and intercellular $\mathrm{CO}_{2}$ concentration $\left(\mathrm{C}_{\mathrm{i}}\right)$, each one of these conditions were separately varied in the leaf chamber, by means of the suitable control provided by the equipment, while remaining conditions were fixed. Unless when varied, PPFD was fixed at $1,200 \mu \mathrm{mol} \mathrm{m}^{-2} \mathrm{~s}^{-1}$, temperature at $30^{\circ} \mathrm{C}$, leaf-to-air vapor-pressure difference $\left(\mathrm{VPD}_{\text {leaf-to-air }}\right)$ between 1.0 and $2.0 \mathrm{kPa}$, and $\mathrm{CO}_{2}$ was used at atmospheric concentration.

For a better adjustment and control of $\mathrm{VPD}_{\text {leaf-to-air, }}$ the leaf chamber was supplied with an air flux with known water vapor pressures from a Dew Point Generator (Li-610, Li-Cor, USA).

Obtained values of $\mathrm{CO}_{2}$ assimilation rates, as a function of PPFD, were adjusted by the equation $\mathrm{A}=\mathrm{A}_{\max }\left[1-\mathrm{e}^{-\mathrm{k}(\mathrm{PPFD}-\mathrm{Ic})}\right]$, where $\mathrm{A}$ is the $\mathrm{CO}_{2}$ assimilation rate, Ic is the light compensation point, and $\mathrm{A}_{\max }$ is the maximum assimilation rate (Prado \& Moraes, 1997). The apparent quantum yield of photosynthesis $(\Phi)$ was estimated as $\Phi=\left(\mathrm{kA}_{\max }\right) \mathrm{e}^{(\mathrm{kIc})}$ (Prado \& Moraes, 1997). Stomatal limitation of photosynthesis (S\%) was also evaluated under optimal conditions as $\mathrm{S} \%=\left[\left(\mathrm{AC}_{\mathrm{i}}-\right.\right.$ $\left.\left.A C_{e}\right) / A_{i}\right] 100$ (Farquhar \& Sharkey, 1982), where $A_{i}$ represents the net photosynthesis, at an internal leaf $\mathrm{CO}_{2}$ pressure of $40 \mathrm{~Pa}$, and $\mathrm{AC}_{\mathrm{e}}$ represents the net photosynthesis at an ambient external $\mathrm{CO}_{2}$ pressure of $40 \mathrm{~Pa}$.

Daily courses of gas exchange parameters were measured in plants exposed to natural conditions, in an 
open area close to the greenhouse. In the day of measurements, air temperature and VPD varied, respectively, from a minimum of $17.2^{\circ} \mathrm{C}$ and $0.18 \mathrm{kPa}$ at $6 \mathrm{~h} 20$ to a maximum of $28.8^{\circ} \mathrm{C}$ and $2.14 \mathrm{kPa}$ at $16 \mathrm{~h}$.

Gas exchange measurements were made by a $\mathrm{LCi}$ Portable Photosynthesis System (ADC, England), and were accompanied by chlorophyll a fluorescence measurements made by a modulated fluorometer (FMS1, Hansatech, England).

Fluorescence measurements were taken by means of the saturation pulse method (Schreiber et al., 1994) for light and 30 min-dark-adapted completely expanded leaves. The intensity and duration of the saturation light pulse were, respectively, $18,000 \mu \mathrm{mol} \mathrm{m}^{-2} \mathrm{~s}^{-1}$ and $0.7 \mathrm{~s}$.

The following parameters were assessed: the maximum quantum yield of photosystem II (PSII) $\left[\mathrm{F}_{\mathrm{v}} / \mathrm{F}_{\mathrm{m}}=\right.$ $\left.\left(F_{m}-F_{0}\right) / F_{m}\right]$, the excitation capture efficiency of PSII open centers $\left(F_{v}{ }^{\prime} / F_{m}{ }^{\prime}=\left(F_{m}{ }^{\prime}-F_{o}{ }^{\prime}\right) / F_{m}{ }^{\prime}\right]$, the effective quantum yield of PSII $\left(\Delta \mathrm{F} / \mathrm{F}_{\mathrm{m}}{ }^{\prime}=\left(\mathrm{F}_{\mathrm{m}}{ }^{\prime}-\mathrm{F}_{\mathrm{s}}\right) / \mathrm{F}_{\mathrm{m}}{ }^{\prime}\right]$, and the nonphotochemical quenching coefficient $\left[\mathrm{NPQ}=\left(\mathrm{F}_{\mathrm{m}}-\right.\right.$ $\left.\left.\mathrm{F}_{\mathrm{m}}{ }^{\prime}\right) / \mathrm{F}_{\mathrm{m}}{ }^{\prime}\right]$, where $\mathrm{F}_{\mathrm{m}}$ and $\mathrm{F}_{\mathrm{o}}$ are, respectively, maximum and minimum fluorescence of dark-adapted leaves; $\mathrm{F}_{\mathrm{m}}$ ' and $\mathrm{F}_{\mathrm{s}}$ are, respectively, maximum and steady state fluorescence in the light-adapted state, and $\mathrm{F}_{\mathrm{o}}{ }^{\prime}$ is minimum fluorescence after far-red illumination of the previously light exposed leaves (Genty et al., 1989; Schreiber et al., 1994). Relative excessive PPFD was calculated as $\left[\left(\mathrm{F}_{\mathrm{v}} / \mathrm{F}_{\mathrm{m}}-\Delta \mathrm{F} / \mathrm{F}_{\mathrm{m}}{ }^{\prime}\right) /\left(\mathrm{F}_{\mathrm{v}} / \mathrm{F}_{\mathrm{m}}\right)\right]$, according to Bilger et al. (1995).

\section{Results and Discussion}

Maximum $\mathrm{CO}_{2}$ assimilation rates (A) of young cashew plants, under optimal temperature, and $V D_{\text {leaf-to-air }}$ were about $13 \mu \mathrm{mol} \mathrm{m}^{-2} \mathrm{~s}^{-1}$, with light saturation of photosynthesis around $1,000 \mu \mathrm{mol} \mathrm{m}^{-2} \mathrm{~s}^{-1}$ (Figure 1), and apparent quantum yield of $0.05 \mu \mathrm{mol} \mathrm{CO}{ }_{2}(\mu \mathrm{mol} \text { photons) })^{-1}$.

Under natural conditions, a maximum $\mathrm{CO}_{2}$ assimilation rate, around $10 \mu \mathrm{mol} \mathrm{m}{ }^{-2} \mathrm{~s}^{-1}$, was attained, indicating a possible limitation of photosynthesis by environmental factors, which were not investigated here. Nonetheless, both $\mathrm{CO}_{2}$ assimilation rates values are within the range described for adult cashew trees in other studies. Under natural conditions, Balasimha (1991) and Palanisamy \& Yadukumar (1993) reported maximum $\mathrm{CO}_{2}$ assimilation rates of about $10 \mu \mathrm{mol} \mathrm{m}^{-2} \mathrm{~s}^{-1}$, while researches in Australia reported values up to $20 \mu \mathrm{mol} \mathrm{m}{ }^{-2} \mathrm{~s}^{-1}$ (Schaper \& Chacko, 1993; Schaper et al., 1996; Blaikie et al., 2001).
Under optimal conditions, the light compensation point in cashew was $28.7 \mu \mathrm{mol} \mathrm{m}^{-2} \mathrm{~s}^{-1}$, a value that approaches the range of 15 to $25 \mu \mathrm{mol} \mathrm{m}{ }^{-2} \mathrm{~s}^{-1}$ presented by Larcher (1995) for tropical tree species.

Maximum $\mathrm{CO}_{2}$ assimilation rates in young cashew were observed between $25^{\circ} \mathrm{C}$ and $35^{\circ} \mathrm{C}$ and, even at $40^{\circ} \mathrm{C}$, photosynthesis in cashew was still around $50 \%$ of its maximum value (Figure 2). This optimum temperature range reveals the species adaptation to tropical climates, since tropical woody plants, in general, present optimum photosynthesis in the range $25^{\circ} \mathrm{C}-30^{\circ} \mathrm{C}$, while for temperate species the optimum range is between $15^{\circ} \mathrm{C}-25^{\circ} \mathrm{C}$ (Fitter \& Hay, 1983).

The response pattern of stomatal conductances to temperature was similar (Figure 2), which may indicate a partial stomatal control over the photosynthetic rates at different temperatures. In fact, intercellular $\mathrm{CO}_{2}$ values presented small increases with increased temperatures (Figure 2). The concomitant analysis of $\mathrm{g}_{\mathrm{s}}$ and $\mathrm{C}_{\mathrm{i}}$ response curves to temperature indicates that, in the range $20^{\circ} \mathrm{C}-35^{\circ} \mathrm{C}$, the increases in $\mathrm{C}_{\mathrm{i}}$ were related to increases in $\mathrm{g}_{\mathrm{s}}$.

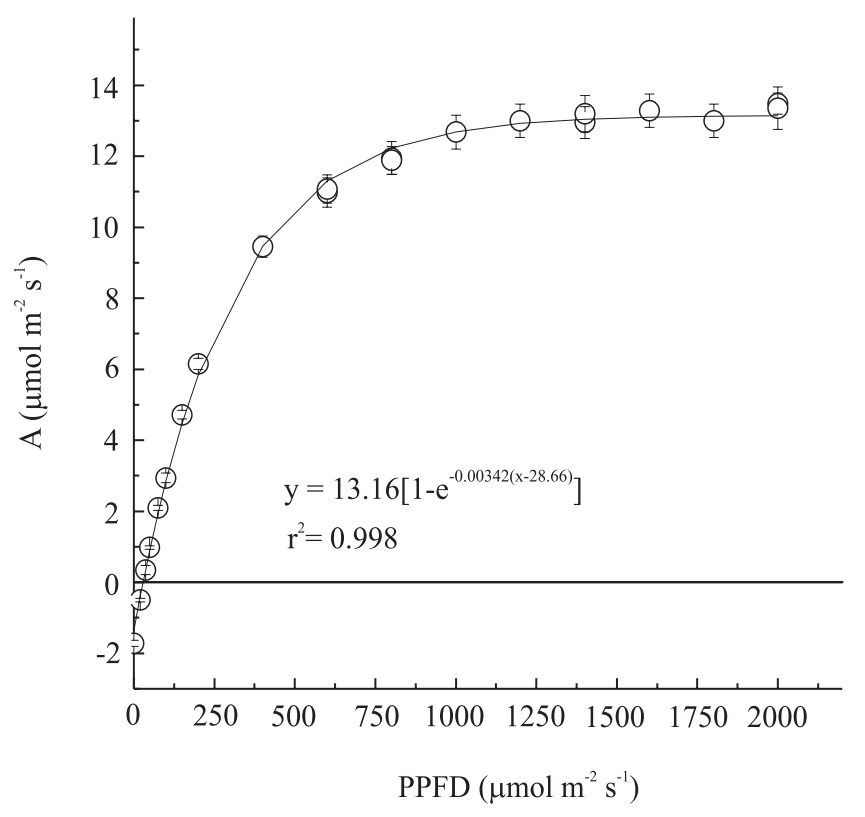

Figure 1. $\mathrm{CO}_{2}$ assimilation rates (A) response to increasing photosynthetic photon flux density (PPFD), in young cashew plants, at $30^{\circ} \mathrm{C}$ leaf temperature, $\mathrm{VPD}_{\text {leaf-to-air }}$ between 1.0 and $2.0 \mathrm{kPa}$ and at atmospheric $\mathrm{CO}_{2}$ concentration. Each point represents the mean value $( \pm \mathrm{SE})$ of four replications taken in different plants. 
Increasing stomatal opening allows a greater $\mathrm{CO}_{2}$ diffusion to the mesophyll (Larcher, 2000), which is important to sustain high photosynthetic rates (Assmann, 1988). However, at temperatures above $35^{\circ} \mathrm{C}$, decreases in $g_{s}$ were accompanied by increases in $\mathrm{C}_{\mathrm{i}}$. Since $\mathrm{C}_{\mathrm{i}}$, at these temperatures, was not limiting photosynthesis, the decrease in A occurred by the interference of non- stomatal factors (Assmann, 1998), which include the activity of carboxylation enzymes of the mesophyll. This activity can be estimated by the rate $\mathrm{A} / \mathrm{C}_{\mathrm{i}}$ (Zhang et al., 2001). Cashew plants showed a strong decrease of the mesophyll carboxylation activity, at temperatures above $35^{\circ} \mathrm{C}$ (Figure 2), indicating a loss of photosynthetic enzymatic activity. In fact, at temperatures above the

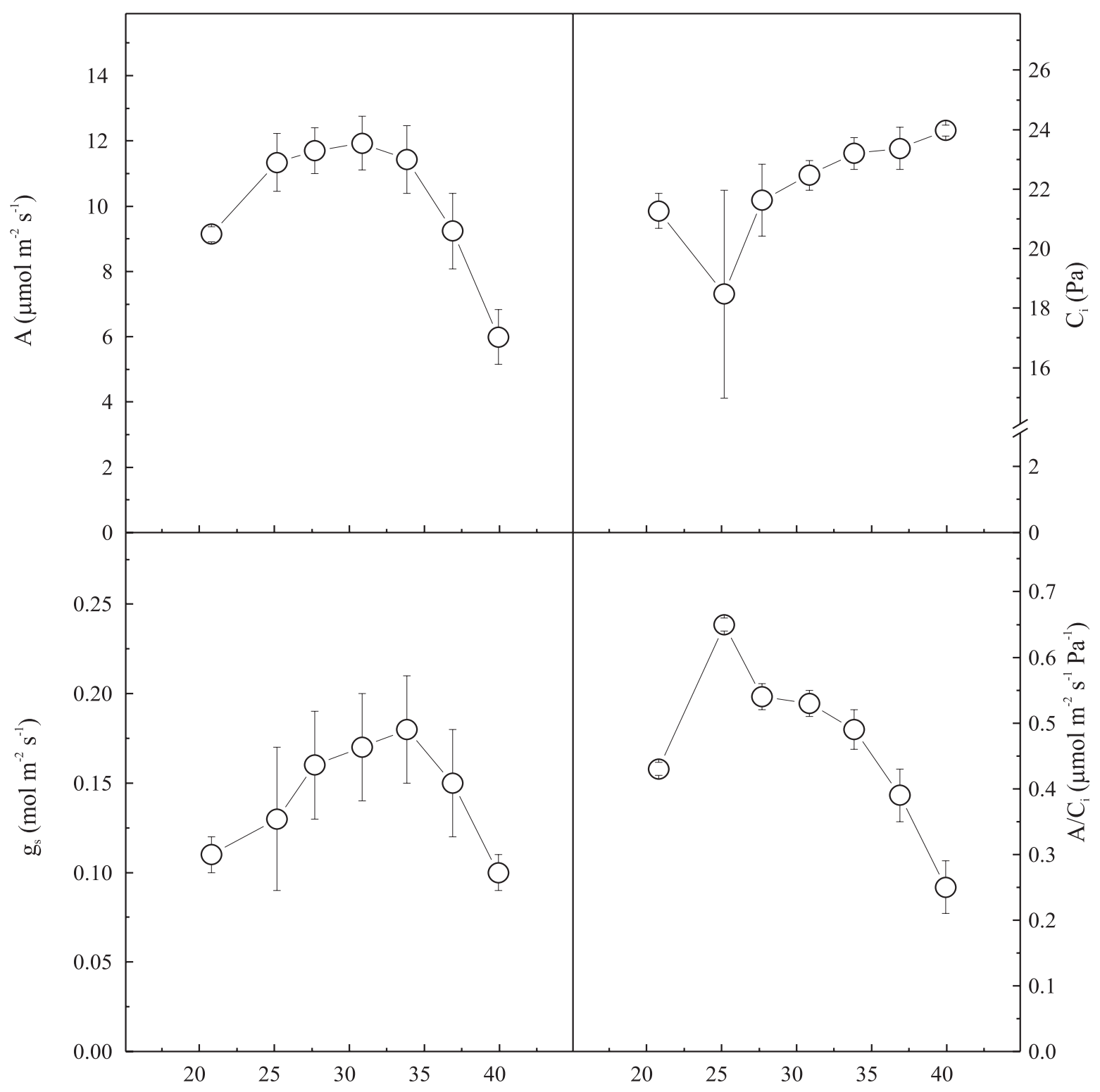

Leaf temperature $\left({ }^{\circ} \mathrm{C}\right)$

Figure 2. $\mathrm{CO}_{2}$ assimilation rates $(\mathrm{A})$, stomatal conductances $\left(\mathrm{g}_{\mathrm{s}}\right)$, intercellular $\mathrm{CO}_{2}$ concentrations $\left(\mathrm{C}_{\mathrm{i}}\right)$, and mesophyll carboxylation $\left(A / C_{i}\right)$ responses to increasing leaf temperature, in young cashew plants, at $1,200 \mu \mathrm{mol} \mathrm{m}^{-2} \mathrm{~s}^{-1}$ $\mathrm{PPFD}, 1.0 \mathrm{kPa} V \mathrm{VD}_{\text {leaf-to-air }}$ and at atmospheric $\mathrm{CO}_{2}$ concentration. Each point represents the mean value $( \pm \mathrm{SE})$ of three replications taken in different plants. 
optimum range, the activity of Rubisco (ribulose-1,5bisphosphate carboxylase) is affected (Weis \& Berry, 1988).

The $\mathrm{CO}_{2}$ compensation point, calculated from the assimilation response curve to intercellular $\mathrm{CO}_{2}$ concentration, was about $6 \mathrm{~Pa}$ (Figure 3), a slightly lower value in relation to that reported by Balasimha (1991) for adult trees, which was between 8 and $10 \mathrm{~Pa}$. The carboxylation efficiency, estimated from the same curve as its initial slope (Farquhar \& Sharkey, 1982), was $0.068 \mu \mathrm{mol} \mathrm{m}^{-2} \mathrm{~s}^{-1} \mathrm{~Pa}^{-1}$. Another important parameter

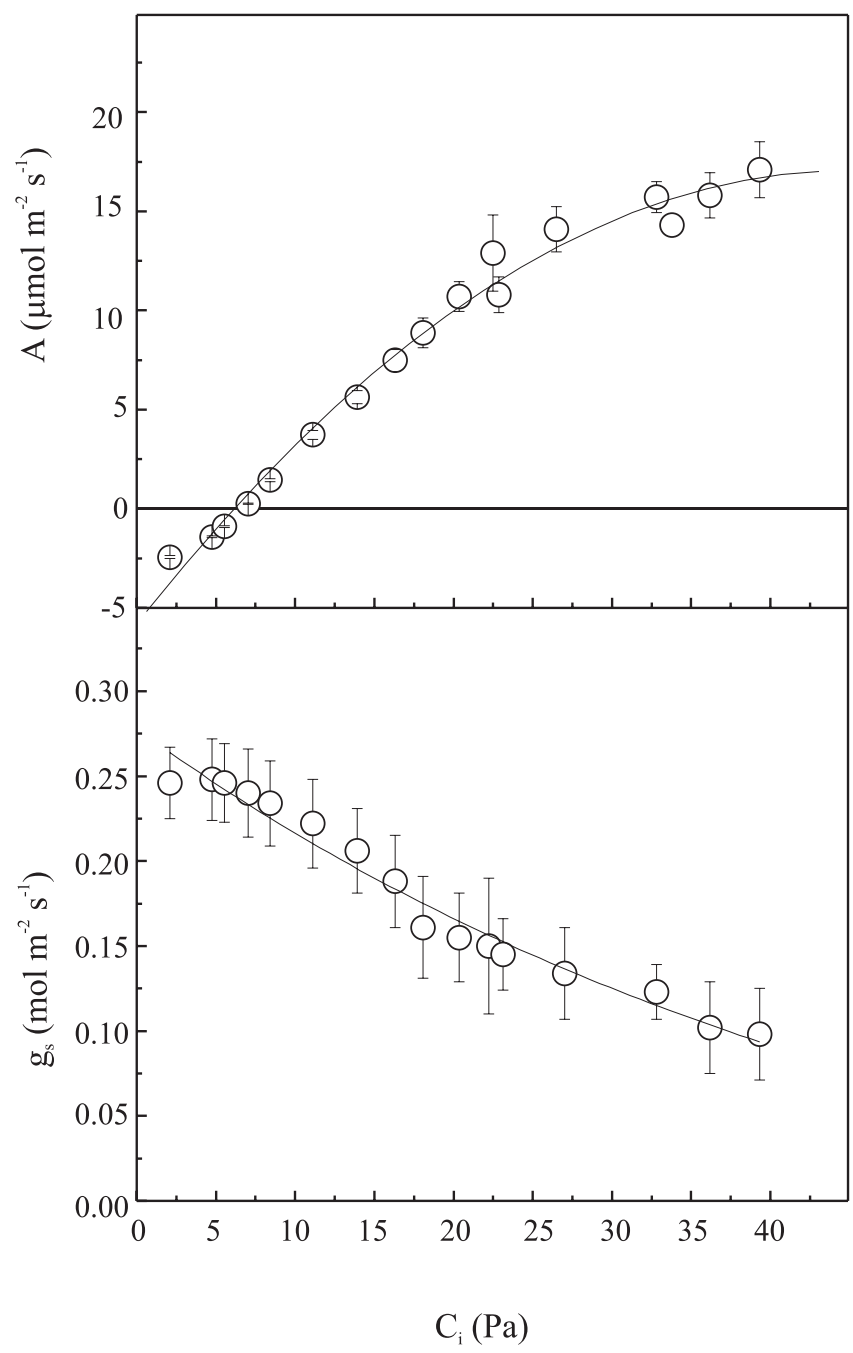

Figure 3. $\mathrm{CO}_{2}$ assimilation rates (A) and stomatal conductances $\left(\mathrm{g}_{\mathrm{s}}\right.$ ) responses to increasing intercellular $\mathrm{CO}_{2}$ concentration $\left(\mathrm{C}_{\mathrm{i}}\right)$, at $1,200 \mu \mathrm{mol} \mathrm{m} \mathrm{m}^{-2} \mathrm{~s}^{-1} \mathrm{PPFD}, 30^{\circ} \mathrm{C}$ leaf temperature, and $\mathrm{VPD}_{\text {leaf-to-air }}$ between 1.0 and $2.0 \mathrm{kPa}$. Each point represents the mean value $( \pm \mathrm{SE})$ of four replications taken in different plants. indicated by this curve is the limitation imposed by stomata on the photosynthesis (Farquhar \& Sharkey, 1982), which in cashew plants under optimal temperature and irradiance, was of $24.6 \%$, so that the photosynthetic capacity of mesophyll cells must contribute with more than $70 \%$ of limitation.

Stomata showed sensitivity to $\mathrm{CO}_{2}$ with decreasing stomatal conductances when increasing intercellular $\mathrm{CO}_{2}$ concentration (Figure 3). This kind of response can be viewed as a part of a mechanism to minimize water loss, under conditions in which $\mathrm{CO}_{2}$ is not limiting photosynthesis (Farquhar \& Sharkey, 1982). Accordingly, Eamus (1991) suggested that, under high $\mathrm{CO}_{2}$ concentrations, reductions in stomatal conductances, associated with the higher $\mathrm{CO}_{2}$ assimilation rates, contribute to increase water use efficiency.

Varying vapor-pressure deficits had a small effect on $\mathrm{CO}_{2}$ assimilation rates. These rates were maintained at relatively high values in the $\mathrm{VPD}_{\text {leaf-to-air }}$ range, $1.0-3.5 \mathrm{kPa}$, despite small decreases above $2.5 \mathrm{kPa}$ (Figure 4). Balasimha (1991) also found, for adult trees in India, that cashew photosynthesis was not substantially affected by VPD in the range $2.0-4.0 \mathrm{kPa}$. Stomata, however, were strongly affected by $\mathrm{VPD}_{\text {leaf-to-air, with an }}$ observed gradual closure above $1.5 \mathrm{kPa}$ (Figure 4). The reduced stomatal conductances, at high $\mathrm{VPD}_{\text {leaf-to-air, }}$ were efficient in restricting water losses by transpiration. In the absence of any change in stomatal conductances, the ratio of transpiration, for a leaf maintained at constant temperature, is expected to be directly proportional to VPD (Morison \& Gifford, 1983). However, in cashew plants, transpiration rates were kept constant over the range 2.0-3.5 $\mathrm{kPa}$ (Figure 4), due to the stomatal closure. Internal $\mathrm{CO}_{2}$ was little affected by stomatal closure, which can explain the maintenance of high $\mathrm{CO}_{2}$ assimilation rates, at relatively high $\mathrm{VPD}_{\text {leaf-to-air. }}$. In general, the response of cashew plants to increasing VPD ${ }_{\text {leaf-to-air }}$ may demonstrate some adaptability to dry environments, since plants can maintain relatively high photosynthetic activity, under conditions of accentuated vapor-pressure deficits.

Daily courses of photosynthetic activity demonstrated that $\mathrm{CO}_{2}$ assimilation rates were saturated in early morning, following thereafter the PPFD changes (Figure 5). The decrease of PPFD around midday, because of the presence of clouds, was accompanied by decreases in $\mathrm{CO}_{2}$ assimilation rates and stomatal conductance (Figure 5).

Blaikie \& Chacko (1998) showed that gas exchange was closely related to fluctuation in stomatal 
conductances, with these values generally being lower in the afternoon than in the morning. These observations are also valid for this study, since curves of $\mathrm{CO}_{2}$ assimilation rates and stomatal conductances varied similarly during the day. Transpiration rates were greater in the afternoon, reaching a peak around 14h (Figure 5).
The maximum quantum yield of PSII, as assessed by $\mathrm{F}_{\mathrm{v}} / \mathrm{F}_{\mathrm{m}}$ ratio, was optimum in early morning (around 0.8 ), decreasing to a minimum value (around 0.6 ) at $11 \mathrm{~h}$. A small recovery began to occur during the afternoon (Figure 6). Small decreases of $F_{v} / F_{m}$ ratio during the day were also observed by Blaikie \& Chacko (1998),

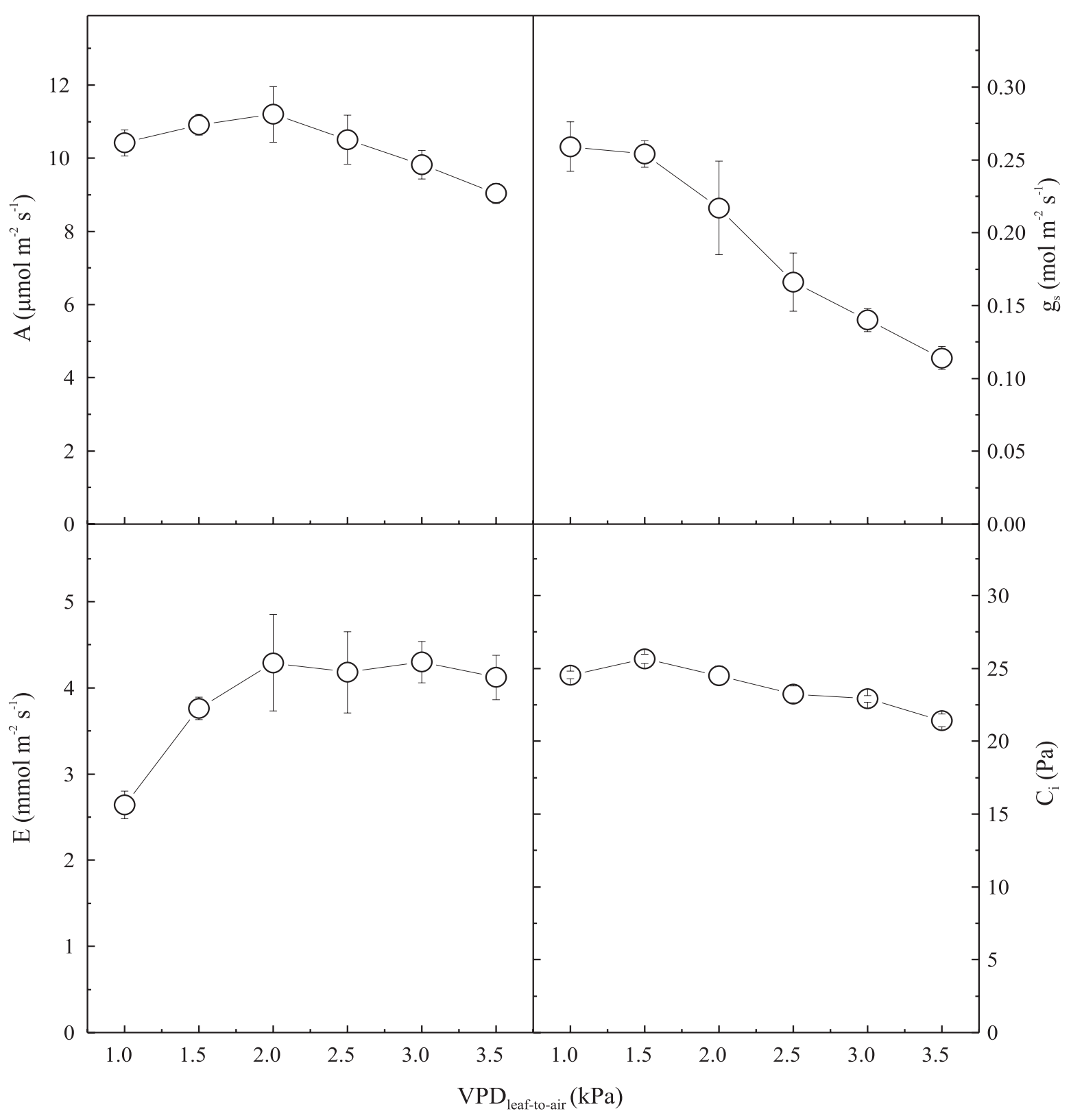

Figure 4. $\mathrm{CO}_{2}$ assimilation rates (A), stomatal conductances $\left(\mathrm{g}_{\mathrm{s}}\right)$, transpiration rates (E), and intercellular $\mathrm{CO}_{2}$ concentration $\left(C_{i}\right)$ responses to increasing $V_{\text {PPD }}$ leaf-to-air, in young cashew plants at $1,200 \mu \mathrm{mol} \mathrm{m}^{-2} \mathrm{~s}^{-1} \mathrm{PPFD}, 30^{\circ} \mathrm{C}$ leaf temperature and at atmospheric $\mathrm{CO}_{2}$ concentration. Each point represents the mean value $( \pm \mathrm{SE})$ of five replications taken in different plants. 
indicating photoinhibition of photosynthesis in cashew plants (Bolhàr-Nordenkampk \& Öquist, 1993). This phenomenon occurs when the amount of energy, intercepted by photosynthetic apparatus, exceeds the capacity of its utilization in photochemical reactions (Krause, 1988).
$\mathrm{F}_{\mathrm{v}} / \mathrm{F}_{\mathrm{m}}$ decreases may be either the result of some photosynthetic damage or photoprotective mechanisms (Osmond, 1994). Although the distinction between photoprotection and photodamage is not always clear, protective photoinhibition is recognized by a rapid recovery of $\mathrm{F}_{\mathrm{v}} / \mathrm{F}_{\mathrm{m}}$ ratio after a dark adaptation period.

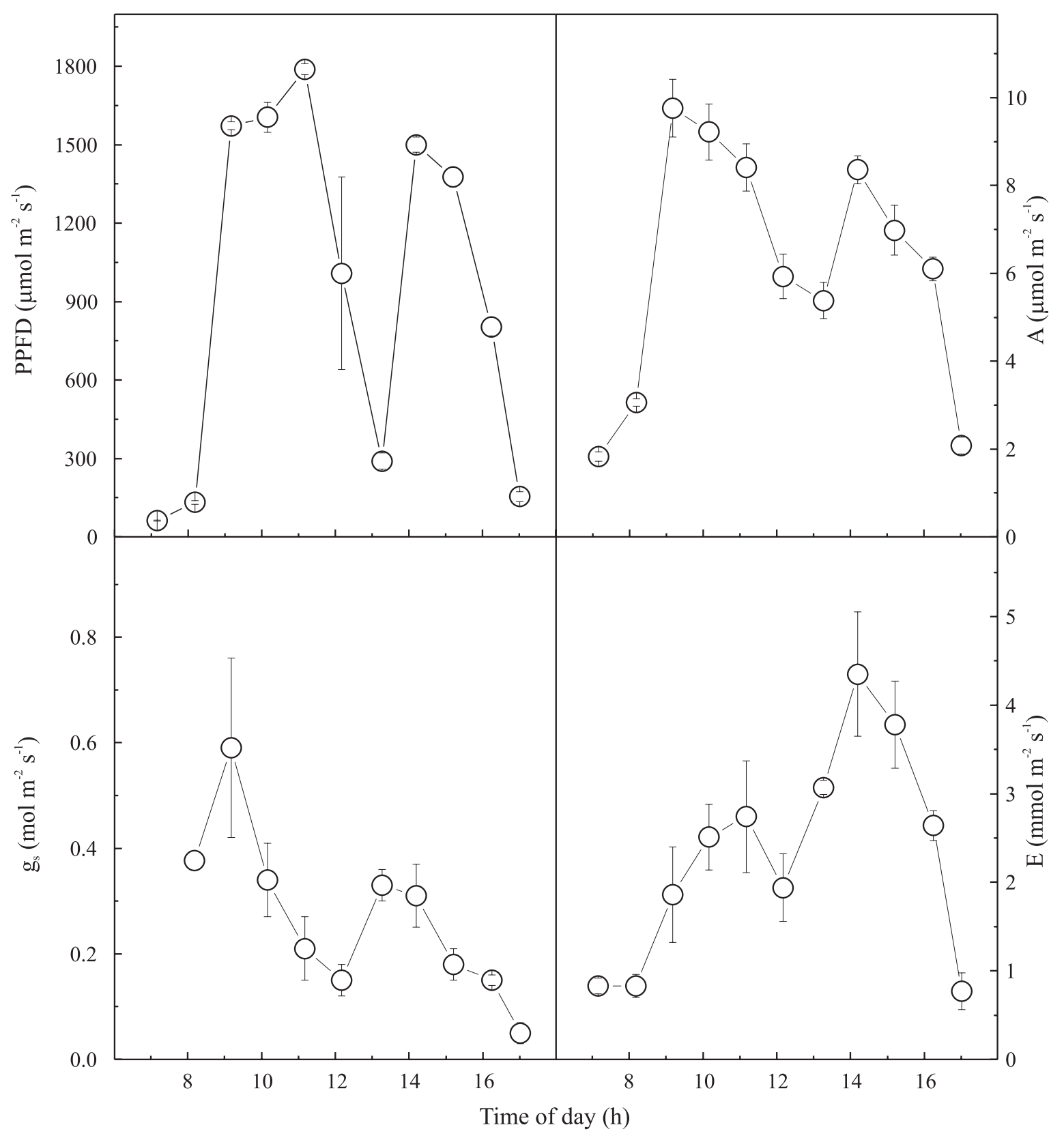

Figure 5. Daily courses of photosynthetic photon flux density (PPFD) and associated $\mathrm{CO}_{2}$ assimilation rates (A), stomatal conductances $\left(g_{s}\right)$ and transpiration rate $(E)$, in young cashew plants. Each point represents the mean value $( \pm \mathrm{SE})$ of five replications taken in different plants. 
It may involve changes in PSII antenna, which favors the dissipation of excess energy as heat (Osmond, 1994). In cashew plants, $\mathrm{F}_{\mathrm{v}} / \mathrm{F}_{\mathrm{m}}$ decrease was only transient, showing a slight recovery during afternoon, and a complete overnight recovery, since morning values were always in the optimum range. These results indicate that, at least, no permanent PSII damage occurred.

The decrease in the excitation capture efficiency of PSII (Figure 6) is consistent with the occurrence of photoprotection, as well as the observed increases in non-

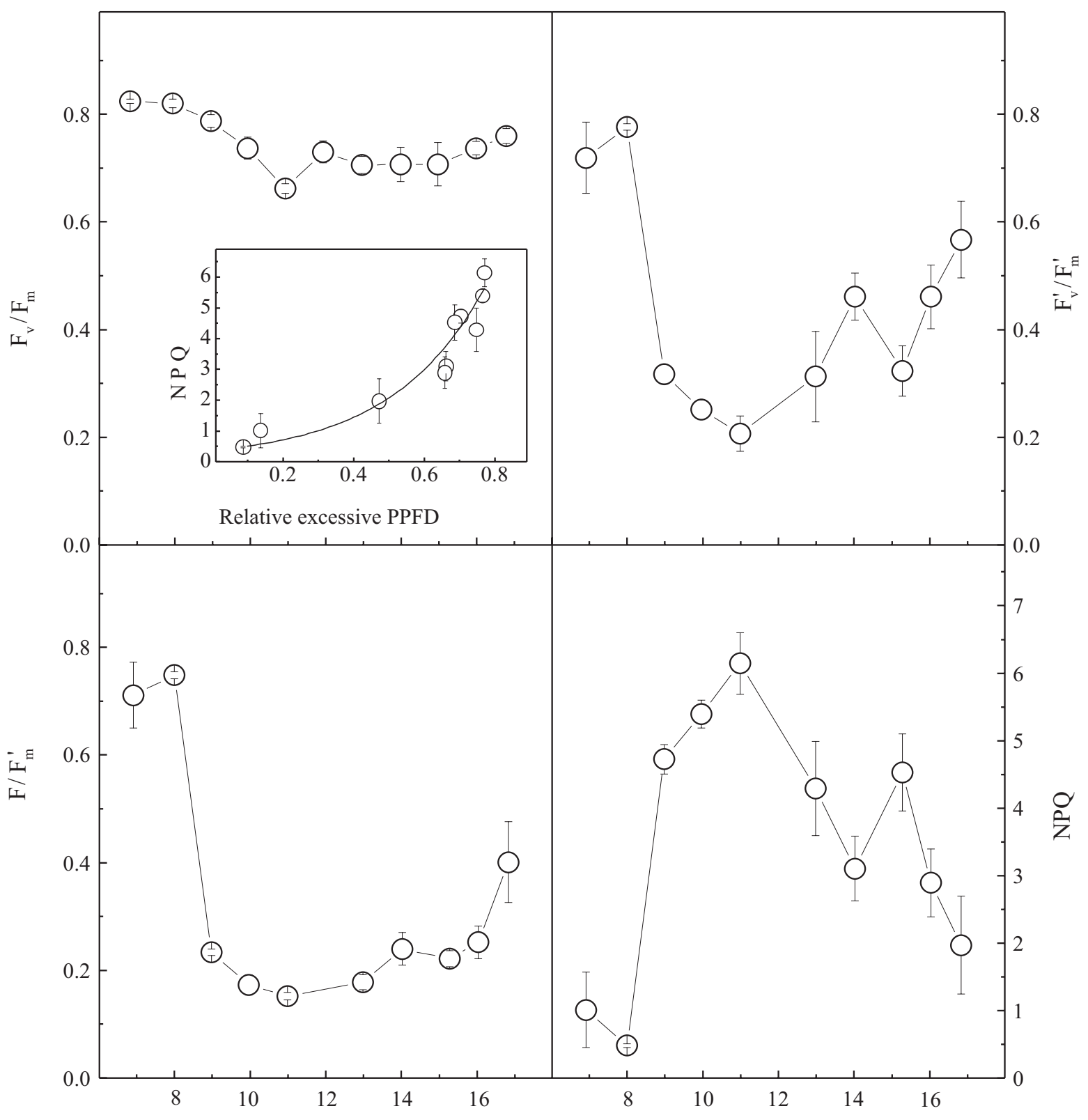

Time of day (h)

Figure 6. Daily courses of chlorophyll a fluorescence parameters, in young cashew plants under natural conditions, showing maximum quantum yield of PSII $\left(\mathrm{F}_{\mathrm{v}} / \mathrm{F}_{\mathrm{m}}\right)$, excitation capture efficiency by PSII open centers $\left(\mathrm{F}_{\mathrm{v}}{ }^{\prime} / \mathrm{F}_{\mathrm{m}}{ }^{\prime}\right)$, effective quantum yield of PSII $\left(\Delta \mathrm{F} / \mathrm{F}_{\mathrm{m}}{ }^{\prime}\right)$, nonphotochemical quenching coefficient (NPQ), and NPQ as function of the relative excessive photosynthetic photon flux density (PPFD). Each point represents the mean value $( \pm$ SE) of five replications taken in different plants. 
photochemical quenching during the day, particularly around 11h, and under increased relative excessive PPFD.

As a consequence, the values of effective quantum yield of PSII, that were high in early morning, decreased to 0.2 and remained at low values until 16h. Here again, these values of effective quantum yield were similar to those reported in other studies (Blaikie \& Chacko, 1998; Blaikie et al., 2001). Since no damages to the photosynthetic system were evident, the photoinhibition in young cashew plants was effective in protecting the photochemical apparatus, at the high irradiance levels, to which plants were exposed in their natural environments.

\section{Conclusions}

1. Leaf temperatures, between $25^{\circ} \mathrm{C}$ and $35^{\circ} \mathrm{C}$, are optimal for photosynthesis in young cashew plants, revealing the species adaptation to tropical climates.

2. Under high vapor-pressure deficits, stomatal closure of young cashew plants can be efficient in restricting water losses by transpiration.

3. Young cashew plants can maintain relatively high photosynthetic activity, under conditions of accentuated vapor-pressure deficits, which associated with the stomatal response pattern, can be considered an species adaptation to dry environments.

4. Under natural conditions of high irradiance, young cashew plants show photoinhibition of photosynthesis, protecting the photosynthetic apparatus from permanent photodamage.

\section{Acknowledgements}

To Conselho Nacional de Desenvolvimento Científico e Tecnológico (CNPq), and to Fundação de Amparo à Pesquisa do Estado de São Paulo (Fapesp) for financial support.

\section{References}

ASSMANN, S.M. Stomatal and nonstomatal limitations to carbon assimilation: an evaluation of the path-dependent method. Plant, Cell and Environment, v.11, p.577-582, 1988.

BALASIMHA, D. Photosynthetic characteristics of cashew trees. Photosynthetica, v.25, p.419-423, 1991.

BARROS, L.M.; CAVALCANTI, J.J.V.; PAIVA, J.R.; CRISÓSTOMO, J.R.; CORRÊA, M.P.F.; LIMA, A.C. Seleção de clones de cajueiro-anão para o plantio comercial no Estado do Ceará. Pesquisa Agropecuária Brasileira, v.35, p.2197-2204, 2000.

BILGER, W.; SCHREIBER, U.; BOCK, M. Determination of the quantum efficiency of photosystem II and of nonphotochemical quenching of chlorophyll fluorescence in the field. Oecologia, v.102, p.425-432, 1995.

BLAIKIE, S.J.; CHACKO, E.K. Sap flow, leaf gas exchange and chlorophyll fluorescence of container-grown cashew (Anacardium occidentale L.) trees subjected to repeated cycles of soil drying. Australian Journal of Experimental Agriculture, v.38, p.305311, 1998.

BLAIKIE, S.J.; CHACKO, E.K.; LU, P.; MÜLLER, W.J. Productivity and water relations of field-grown cashew: a comparison of sprinkler and drip irrigation. Australian Journal of Experimental Agriculture, v.41, p.663-673, 2001.

BOLHÀR-NORDENKAMPF, H.R.; ÖQUIST, G. Chlorophyll fluorescence as a tool in photosynthesis research. In: HALL, D.O.; SCURLOCK, J.M.O.; BOLHÀR-NORDENKAMPF, H.R.; LEEGOOD, R.C.; LONG, S.P. (Ed.). Photosynthesis and production in a changing environment: a field and laboratory manual. London: Chapman and Hall, 1993. p.193-206.

EAMUS, D. The interaction of rising $\mathrm{CO}_{2}$ and temperatures with water use efficiency. Plant, Cell and Environment, v.14, p.843852, 1991.

FARQUHAR, G.D.; SHARKEY, T.D. Stomatal conductance and photosynthesis. Annual Review of Plant Physiology, v.33, p.317345, 1982.

FITTER, A.H.; RAY, R.K.M. Environmental physiology of plants. London: Academic Press, 1983. 355p.

GENTY, B.; BRIANTAIS, J.M.; BAKER, N.R. The relationship between the quantum yield of photosynthetic electron transport and quenching of chlorophyll fluorescence. Biochimica et Biophysica Acta, v.990, p.87-92, 1989.

HOAGLAND, D.R.; ARNON, D.I. The water-culture method for growing plants without soil. Berkeley: University of California; Agricultural Experiment Station, 1938. 39p.

KRAUSE, G.H. Photoinhibition of photosynthesis: an evaluation of damaging and protective mechanisms. Physiologia Plantarum, v.74, p.566-574, 1988.

LARCHER, W. Carbon utilization and dry matter production. In: LARCHER, W. (Ed.). Physiological plant ecology: ecophysiology and stress physiology of functional groups. $3^{\text {rd }}$ ed. Berlin: Springer, 1995. p.57-166.

LARCHER, W. Ecofisiologia vegetal. São Carlos: Rima Artes e Textos, 2000. 531p.

LIMA, V.P.M.S. A cultura do cajueiro no Nordeste do Brasil. Fortaleza: Banco do Nordeste do Brasil; Escritório Técnico de Estudos Econômicos do Nordeste, 1988. 486p.

MARLER, T.E.; GEORGE, A.P.; NISSEN, R.J.; ANDERSEN, P.C. Miscellaneous tropical fruits. In: SCHEFFER, B.; ANDERSEN, P.C. (Ed.). Handbook of environmental physiology of fruit crops: subtropical and tropical crops. Boca Raton: CRC Press, 1994. v.2. p.199-224.

MENDES-FERRÃO, J.E. O cajueiro. Lisboa: Instituto de Investigação Científica Tropical, 1995. 299p.

MORISON, J.I.L.; GIFFORD, R.M. Stomatal sensitivity to carbon dioxide and humidity. Plant Physiology, v.71, p.789-796, 1983. 
OSMOND, C.B. What is photoinhibition? Some insights from comparisons of shade and sun plants. In: BAKER, N.R.; BOWYER, J.R. (Ed.). Photoinhibition of photosynthesis: from molecular mechanisms to the field. Lancaster: Scientific Publishers, 1994. p.1-24.

PALANISAMY, K.; YADUKUMAR, N. Photosynthesis in relation to radiation and leaf position in cashew trees. Photosynthetica, v.29, p.113-116, 1993.

PRADO, C.H.B.A.; MORAES, J.A.P.V. Photosynthetic capacity and specific leaf mass in twenty woody species of Cerrado vegetation under field conditions. Photosynthetica, v.33, p.103-112, 1997.

SCHAPER, H.; CHACKO, E.K. Effect of irradiance, leaf age, chlorophyll content and branch-girdling on gas exchange of cashew (Anacardium occidentale L.) leaves. Journal of Horticultural Science, v.68, p.541-550, 1993.

SCHAPER, H.; CHACKO, E.K.; BLAIKIE, S.J. Effect of irrigation on leaf gas exchange and yield of cashew in Northern Australia. Australian Journal of Experimental Agriculture, v.36, p.861-868, 1996.
SCHREIBER, U.; BILGER, W.; NEUBAUER, C. Chlorophyll fluorescence as a nonintrusive indicator for rapid assessment of in vivo photosynthesis. In: SCHULZE, E.D.; CALDWELL, M.M. (Ed.). Ecophysiology of photosynthesis. Berlin: Springer, 1994. p.49-70. (Ecological Studies, 100).

VIÉGAS, R.A.; MELO, A.R.B.; SILVEIRA, J.A.G. Nitrate reductase activity and proline accumulation in cashew in response to $\mathrm{NaCl}$ salt shock. Revista Brasileira de Fisiologia Vegetal, v.11, p.21-28, 1999.

VIÉGAS, R.A.; SILVEIRA, J.A.G. Ammonia assimilation and proline accumulation in young cashew plants during long term exposure to $\mathrm{NaCl}$ salinity. Revista Brasileira de Fisiologia Vegetal, v.11, p.153-159, 1999.

WEIS, E.; BERRY, J.A. Plants and high temperature stress. In: LONG, S.P.; WOODWARD, F.I. (Ed.). Plants and temperature. Cambridge: Company of Biologists, 1988. p.329-346.

ZHANG, S.; LI, Q.; MA, K.; CHEN, L. Temperature-dependent gas exchange and stomatal/nonstomatal limitation to $\mathrm{CO}_{2}$ assimilation of Quercus liaotungensis under midday higher irradiance. Photosynthetica, v.39, p.383-388, 2001.

Received on July 14, 2004 and accepted on March 7, 2005 